\title{
Negara Asal Produk, Persepsi Kualitas dan Merek: Pengaruhnya terhadap Keputusan Pembelian Smartphone
}

\author{
Mahardika Ardaka Saputra \\ FEB Universitas Jambi \\ e-mail: mahadikaardaka@gmail.com \\ Ade Octavia \\ FEB Universitas Jambi \\ e-mail: octaviafeunja@yahoo.com \\ Suswita Roza \\ FEB Universitas Jambi \\ e-mail:susieroza@yahoo.com \\ Yayuk Sriayudha \\ FEB Universitas Jambi \\ e-mail: yayuksriayudha@gmail.com
}

\begin{abstract}
This study aims to examine the effect of country of origin, perceived quality and brand on smartphone purchasing decisions. The subject of this study is a smartphone that is sold officially in Indonesian market. The sampling technique used was purposive sampling with the number of samples used amounting to 120 samples which were active users of smartphones. Validity and reliability test results show that the research instrumentsare valid and reliable. The analysis technique used is multiple linear regression analysis using SPSS version 22 software. The results show that country of origin variables partially do not have a positive and significant effect on purchasing decisions while perceived quality and brand variablespartially positive and significant influence purchasing decisions. Simultaneously, country of origin variables, perceived quality and brand have a positive and significant effect on purchasing decisions.
\end{abstract}

Keywords: country of origin, perceived quality, brand, purchase decision

\section{PENDAHULUAN}

Teknologi kini berkembang menjadi tidak bisa dipisahkan dari bidang ekonomi dan bisnis. Teknologi bukan lagi menjadi pilihan namun menjadi kaharusan bagi suatu perusahaan maupun suatu negara untuk menetapkan strategu-strategi pembangunan. Perkembangan teknologi informasi dan komunikasi juga bergerak semakin pesat terutama di era globalisasi saat sekarang ini. Terbukti seperti penggunaan perangkat smartphone dan gadget yang tak lepas dari kehidupan bahkan menjadi kebutuhan setiap individu sebagai alat komunikasi.

Di abad ke 21, smartphone telah berkembang menjadi kebutuhan bagi sebagian besar konsumennya dipandang dari semua dimensi demografis (Persaud \& Azhar, 2012). Kehadiran smartphone juga mempermudah individu untuk berinteraksi dan memperoleh informasi dari seluruh belahan dunia yang dapat diakses melalui jaringan internet kapanpun dan dimanapun. Menurut Filieri et al. (2017), smartphone lebih dari sebuah telepon genggam yang memiliki penambahan 
sistem operasi (iOs, Android), konektifitas internet, video, kamera, perangkat musik, aplikasi GPS dan kapasitas penyimpanan data yang besar.

Saat ini, rata-rata penetrasi smartphone bejumlah dua pertiga dari pengguna telphon genggam di Amerika Serikat (Nielsen, 2014). Sementara pengguna smartphone di China telah menjadi yang terbesar di dunia dengan jumlah lebih dari 1 Miliar pengguna di tahun 2015 (eMarketer, 2015). Indonesia sendiri kini telah menjadi pasar yang sangat potensial untuk berkembangnya teknologi yang menggunakan smartphone.

Hasil survei Asosiasi Penyelenggara Jasa Internet Indonesia (APJII) sepanjang 2017 menyebutkan masyarakat Indonesia ternyata lebih gemar untuk menggunakan smartphone mereka dalam mengakses internet. Saat ini Indonesia termasuk negara dengan pengguna smartphone terbanyak di dunia. Hal ini membuat para perusahaan smartphone sangat gencaruntuk meluncurkan produk-produk smartphone dengan berbagai model, tipe, fitur, design, dan spesifikasi lainnya secara berkala yang menghadirkan inovasi-inovasi terbaru agar dapat memenuhi kebutuhan pasar. Lembaga riset pasar IDC merilis laporan triwulanan Mobile Phone Tracker untuk Kuartal IV 2017 bahwa angka pengiriman smartphone di Indonesia tercatat mencapai 7,8 juta unit sepanjang periode tersebut dengan total pengiriman sebanyak 30,4 juta unit.

Banyak jenis smartphone yang beredar di pasaran dengan berbagai merek, baik yang berasal dari luar negeri maupun dalam negeri sehingga konsumen mempunyai banyak pilihan serta menuntut konsumen untuk berhati-hati dalam menentukan pilihan. Apabila konsumen tidak mengenal suatu produk dari suatu negara maka konsumen akan menduga-duga tentang informasi suatu produk yang akhirnya akan mempengaruhi keputusan pembelian. Hal ini karena selain perusahaan yang membuat produk, negara asal atau lokasi geografis dari produk (Country of Origin) juga dihubungkan dengan merek dan menghasilkan kesan tambahan bagi konsumen (Keller, 2013). Country of origin akan mempengaruhi produk yang nantinya akan menimbulkan persepsi kualitas akan baik buruknya suatu produk. Semakin tinggi nilai yang diperoleh oleh konsumen maka keputusan pembelian produk tersebut juga semakin tinggi.

Negara asal (country of origin) mengacu pada negara dimana suatu merek berasal atau dihubungkan. Di negara-negara maju, masyarakat cenderung untuk membeli produk-produk lokal dibandingkan produk import. Namun di negara-negara berkembang, masyarakat justru menyukai produk dari luar negeri karena percaya memiliki kualitas yang tinggi. Suatu negara sebagai country of origin biasanya dihubungkan dengan persepsi kualitas dari produk yang diproduksi.

Aaker (1991) dalam Sara dan Edura (2015) menyatakan bahwa persepsi kualitas merupakan keseluruhan atau keunggulan produk dan merek sehubungan dengan tujuan yang dimaksudkan seperti tujuan pembelian. Tiap merek dari suatu negara akan digambarkan dengan atribut-atribut tertentu yang mempengaruhi keputusan pembelian. Keyakinan konsumen tentang atribut tersebut sering menentukan kualitas dan pada gilirannya, mempengaruhi sikap dan perilaku terhadap suatu merek (Keller, 2013).

Sebuah merek juga menjadi dasar pertimbangan bagi konsumen untuk memutuskan membeli produk. Czinkota dan Ronkainen (2013) menyatakan bahwa merek adalah faktor kunci di balik keputusan untuk membeli baik dalam situasi sebagai konsumen atau bisnis-ke-bisnis.Merek dapat menjadi ciri khas yang membedakan suatu produk dengan produk sejenis lainnya sehingga dapat memudahkan konsumen untuk mengingat suatu produk termasuk smartphone. Konsumen dapat mengevaluasi produk yang sejenis secara berbeda berdasarkan bagaimana merek dari produk tersebut (Kotler dan Keller, 2016).

Tanggapan konsumen merupakan alat penguji untuk sebuah strategi pemasaran. Salah satu ukuran keberhasilan pemasaran adalah bagaimana persepsi konsumen dapat meningkatkan kepercayaan konsumen atas suatu produk sehingga mereka memiliki keinginan membeli yang sangat besar terhadap produk tersebut. Hal ini dapat 
diketahui dengan memberi penilaian persepsi konsumen. Persepsi konsumen terhadap suatu produk akan menjadi pertimbangan konsumen dalam menentukan pilihan produk mana yang akan dibeli. Jika persepsi tersebut tinggi maka konsumen akan tertarik untuk membeli produk tersebut. Untuk menghasilkan persepsi yang tepat bagi konsumen, perusahaan hendaknya memperhatikan kriteria evaluasi kualitas produk dan jasa yang ditawarkan (Durianto, 20011).

Semakin berkembangnya berbagai produk smartphone yang berkualitas dengan berbagai merek yang beredar di pasar memberikan konsumen kesempatan untuk memilih produk. Banyaknya merek smartphone yang masuk ke pasar Indonesia menggambarkan bahwa terjadi persaingan yang sangat ketat dalam pasar untuk menjadikan merek produk mereka yang terbaik dan masuk kedalam urutan merek smartphone teratas di pasar Indonesia. Menurut lembaga riset pasar Canalys, posisi top 5 vendor smartphone di Indonesia pada kuartal pertama tahun 2018 diisi oleh Samsung yang berada pada urutan pertama, disusul oleh Xiaomi, Oppo, Vivo, dan Smartfren yang masing-masing berada pada urutan kedua, ketiga, keempat dan kelima. Samsung masih menjadi smartphone pilihan pertama di Indonesia. Pertumbuhan vendor yang berasal dari Korea Selatan naik menjadi 17,2 persen menjadi 25,5 persen pada kuartal pertama 2018. Xiaomi,vendor yang berasal dari Tiongkok berhasil yang menguasai pasar smartphone Indonesia sebesar 18,3 persen, diikuti Oppo sebesar 16,8 persen dan Vivo sebesar 6,5 persen. Menurut laporan riset konsumen dunia Canalys, satu satunya vendor yang mengalami penurunan angka adalah Smartfren dimana pangsa pasarnya menyusut 5,6 persen.

Pemasaran (marketing) adalah upaya mengidentifikasi dan memenuhi kebutuhan manusia dan sosial (Kotler \& Keller, 2016). America Marketing Associaton (AMA) menawarkan definisi formal dari Pemasaran yakni sebagai salah satu fungsi organisasi dan serangkain proses untuk menciptakan, mengkomunikasikan dan memberikan nilai kepada pelanggan dan untuk mengelola hubungan pelanggan melalui cara-cara yang menguntungkan organisasi dan pemangku kepentingan. Manajemen pemasaran adalah sebagai seni dan ilmu memilih pasar sasaran dan meraih, mempertahankan, serta menumbuhkan pelanggan dengan menciptakan, menghantarkan dan mengkomunikasi nilai pelanggan yang unggul (Kotler \& Keller, 2016). Rangkaian tugas yang diperlukan untuk manajemen pemasaran yang sukses yakni mengembangkan strategi dan rencana pemasaran, menangkap wawasan pemasaran, berhubungan dengan pelanggan, membangun merek yang kuat, menciptakan, menyampaikan, dan mengkomunikasikan nilai, dan menciptakan pertumbuhan jangka panjang (Kotler \& Keller, 2016).

Negara Asal Produk (Country of Origin) merupakan negara asal suatu merek yang mempengaruhi niat pembelian yang merupakan elemen penting di dalam mempengaruhi keputusan pembelian suatu produk. Country of origin dipahami sebagai efek yang muncul dalam persepsi konsumen yang dipengaruhi oleh lokasi dimana suatu produk dihasilkan sehingga country of origin mengacu pada negara tempat merek atau tempat produk di produksi (Czinkota \& Ronkainen, 2012). Menurut Shamidra dan Saroj (2011), country of origin sering dikaitkan dengan kualitas produk. Konsumen akan menggunakan country of origin sebagai standar kualitas suatu produk sebelum produk tersebut dibeli.

Persepsi kualitas menurut Keller (2013) dapat didefinisikan sebagai bentuk persepsi konsumen terhadap keseluruhan kualitas atau keunggulan suatu produk atau jasa terhadap alternatif-alternatif yang ada sesuai dengan tujuan yang diinginkan. Persepsi kualitas mencerminkan perasaan pelanggan secara menyeluruh mengenai suatu produk. Untuk memahami persepsi kualitas atas suatu merek diperlukan pengukuran terhadap dimensi yang terkait dengan karakteristik produk. Dimensi tersebut antara lain; kinerja, pelayanan, ketahanan, kehandalan, karakteristik produk, kesesuaian dengan spesifikasi dan hasil (Durianto, 2001). Merek memiliki peranan yang sangat penting bagi suatu produk. 
Merek adalah simbol, nama dan istilah tertentu yang menjadi identitas suatu produk dan dapat memudahkan konsumen untuk mengingat produk tersebut serta dapat menjadi pembeda antara suatu produk dengan produk pesaingnya yang sejenis. Menurut American Marketing Association, merek sebagai nama, istilah, simbol, atau desain, atau kombinasi dari hal-hal tersebut, dimaksudkan mengidentifikasi barang atau jasa dari satu penjual atau kelompok penjual dan untuk membedakan mereka dari para pesaing.

Pembelajaran merupakan faktor berikut nya yang juga berperan dalam mempengaruhi perilaku seorang individu. Proses belajar individu merupakan hasil yang saling mempengaruhi dari unsur dorongan, petunjuk, tanggapan dan penguat yang seringkali menciptakan pengalaman konsumen ketika mengkonsumsi produk. Hasil pembelajaran ini akan tersimpan didalam memori konsumen yang akan dipergunakannya sebagai salah satu dasar pertimbangan ketika muncul kebutuhan yang sama. Faktor terakhir adalah kepercayaan dan sikap yang merupakan pengaruh terhadap para pembeli dan mengembangkan suatu pemahaman mengenai suatu evaluasi kognitif yang menguntungkan atau tidak menguntungkan terhadap suatu objek tertentu (Loudon \& Dellabita, 1999). Dalam membeli dan mengkonsumsi sesuatu, terlebih dahulu konsumen membuat upaya keputusan mengenai produk apa yang dibutuhkan, kapan, bagaimana dan dimana proses pembelian atau konsumsi itu akan terjadi. Dengan kata lain, diperlukan suatu proses pengambilan keputusan untuk membeli sesuatu baik barang atau jasa.

Keputusan pembelian adalah tahap evaluasi konsumen untuk membentuk preferensi di antara merek dalam menetapkan pilihan (Kotler \& Keller, 2016). Urutan kejadian dalam keputusan pembelian yang dikemukakan oleh Kotler dan Keller (2016) antara lain adalah pengenalan masalah, pencarian informasi, evaluasi alternatif, keputusan membeli dan perilaku setelah pembelian. Berdasarkan pemahaman itu, maka dimunculkan dua hipotesis yang dianalisis dalam penelitian ini.
H1: Terdapat pengaruh dari Country of Origin, persepsi kualitas dan merek secara parsial terhadap keputusan pembelian smartphone.

H2: Terdapat pengaruh dari Country of Origin, persepsi kualitas dan merek secara parsial terhadap keputusan pembelian smartphone.

\section{METODE PENELITIAN}

Pendekatan yang digunakan adalah pendekatan kuantitatif yaitu metode untuk menguji teori-teori tertentu dengan cara meneliti hubungan antar variabel. Adapun metode yang digunakan adalah metode survey, yakni metode penelitian kuantitatif yang digunakan untuk mendapatkan data yang terjadi pada masa lampau atau saat ini, tentang keyakinan, pendapat, karakteristik, perilaku, hubungan variabel dan untuk menguji beberapa hipotesis tentang variabel sosiologis dan psikologis dari sampel yang diambil dari populasi tertentu, teknik pengumpulan data dengan pengamatan (wawancara atau kuesioner) yang tidak mendalam, dan hasil penelitian cenderung untuk digeneralisasikan (Sugiyono, 2013).

Sumber data adalah data primer dan data sekunder. Data primer yang dibutuhkan adalah karakteristik responden dan persepsi responden tentang country of origin, persepsi kualitas dan merek hubungan nya dengan keputusan pembelian konsumen smartphone. Data sekunder diperoleh dengan mengkaji informasi data dari berbagai studi literatur dan penelitian yang relevan.

Lokasi penelitian dilakukan di Kota Jambi, dengan populasi yang meliputi pengguna aktif smartphone yang berdomisili di Kota Jambi yang tidak diketahui jumlahnya. Sampel penelitian berjumlah 120 orang responden yang diperoleh dari perhitungan 5 kali jumlah indikator seperti yang direkomendasikan oleh Hair (2010), sementara sifat survey yang berkaitan dengan produk maka besaran sampel berkisar $100-$ 125 unit. Teknik penentuan sampel yang digunakan adalah purposive sampling, yakni teknik penentuan sampel dengan kriteria atau pertimbangan tertentu. (Sugiyono, 2013). Metode pengumpulan data menggunakan 
kuesioner berbasis online melalui google form. Analisis deskriptif digunakan untuk menggambarkan data penelitian yang telah dikumpulkan. Alat analisis yang digunakan adalah analisis regresi linier berganda dengan software SPSS versi 22 untuk mengetahui pengaruh variabel country of origin, persepsi kualitas dan merek secara parsial dan simultan terhadap keputusan pembelian.

\section{HASIL ANALISIS}

\section{Karakteristik Deskriptif}

Responden dalam penelitian ini dibedakan berdasarkan jenis kelamin, usia, pekerjaan, pengeluaran perbulan, merek smartphone yang dimiliki, merek smartphone yang sering digunakan, lama menggunakan smartphone, dan aktifitas yang sering dilakukan saat menggunakan smartphone. Responden yang paling dominan dalam penelitian ini adalah responden berjenis kelamin perempuan yakni sebesar 61,7 persen. Kaum perempuan diidentifikasi cenderung memiliki perasaan ingin mencoba dan memiliki apa yang mereka lihat. Sebagian pendapat lain menyatakan bahwa untuk siklus hormonal gender perempuan dapat mempengaruhi pemilihan produk, kemungkinan besar lebih dalam untuk menggunakannya produk secara detail, memeriksa secara teliti terhadap pesan dan membuat keputusan yang luas berdasarkan atribut produk (Hoyer et al., 2013).

Usia dapat menggambarkan tingkat kematangan emosional individu untuk mengembangkan pemikirannya terutama dalam pengambilan keputusan strategik. Rentang usia responden terbesar yakni responden berusia 17-21 tahun yaitu sebesar 72,5 persen. Persentasi ini menunjukkan pengguna potensial smartphone di dalam penelitian ini didominasi generasi muda dan remaja. Pendidikan turut mempengaruhi pola pikir seseorang dan tingkat pendidikan juga menentukan keputusan seseorang dalam melakukan pembelian.Berdasarkan pekerjaan didominasi oleh pelajar/mahasiswa yakni sebanyak 79,2 persen. Hal ini menunjukkan bahwa sebagian besar konsumen pembeli smartphone adalah kelompok usia produktif yang memiliki ketertarikan produk-produk baru dengan teknologi terkini...Berasarkan pengeluaran per bulan didominasi oleh responden dengan pengeluaran kurang dari Rp. 2.000.000 perbulan yakni sebesar 75,0 persen. Hasil tersebut mengindikasikan bahwa konsumen memiliki daya beli yang cukup terhadap smartphone dan kisaran harga smartphone cukup terjangkau bagi konsumen.

Selanjutnya, berdasarkan merek dari smartphone yang dimiliki oleh responden didominasi oleh merek smartphone Samsung dan Xiaomi yang keduanya sama-sama sebesar 18,34 persen. Berdasarkan smartphone yang paling sering digunakan didominasi oleh merek Samsung yakni sebesar 29,2 persen. Menurut Sriayudha (2013) produk-produk Samsung mengalami tingkat penjualan yang signifikan setiap tahunnya dan produk Samsung berhasil merebut pasar smartphone Asia termasuk di Indonesia. Berdasarkan lama menggunakan merek smartphone didominasi oleh responden yang telah menggunakan smartphone lebih dari 1,5 tahun yakni sebanyak 49,2persen. Untuk jangka waktu lebih dari 1 tahun responden sudah bisa merasakan kelebihan dan manfaat fitur yang ada di dalam smartphone sehingga konsumen bisa melakukan penilaian spesifik terhadap produk tersebut. Berdasarkan aktifitas yang sering dilakukan saat menggunakan smartphone didominasi oleh responden yang sering menggunakan smarphone untuk akses internet yakni sebesar 63,5 persen. Teknologi media sosial yang semakin maju menyebabkan internet menjadi salah satu media yang tidak hanya untuk berkomunikasi, tapi juga media yang menghubungkan satu individu dengan individu lainnya yang tidak dibatasi jarak dan waktu serta berbagi ide-ide mengenai ragam inovasi produk.

Penilaian responden berdasarkan variabel negara asal produk (Country of Origin), persepsi kualitas dan merek yang terdiri dari 22 indikator. Variabel negara asal produk (Country of Origin) terdiri dari 7 (tujuh) indikator memiliki total skor rata-rata sebesar 3,55 yang berarti dalam kategori baik. Variabel persepsi kualitas terdiri dari 7 (tujuh) indikator memiliki skor rata-rata sebesar 3,95 yang berarti dalam kategori baik. Variabel 
merek terdiri dari 4 (empat) indikator memiliki skor rata-rata sebesar 3,96 yang berarti dalam kategori baik. Variabel keputusan pembelian yang terdiri dari 4 (empat) indikator memiliki skor rata-rata 4,25 yang berarti dalam kategori sangat baik.

\section{Uji Validitas dan Reliabilitas}

Uji Validitas dilakukan pada 31 responden yang merupakan pengguna aktif smartphone di Kota Jambi dengan taraf signifikan sebesar 5\%, sehingga diperoleh nilai $r_{\text {tabel }}$ sebesar 0,355. Berdasarkan hasil uji validitas menunjukkan bahwa semua nilai $r_{\text {hitung }}>r_{\text {tabel }}$ yakni 0.355 yang artinya semua pernyataan dalam instrumen penelitian dikatakan valid. Suatu instumen dikatakan variabel apabila memiliki nilai Cronbanch alpha yang lebih tinggi dari yang disyaratkan, yakni sebesar 0,6. Pada hasil uji reliabilitas dari 31 responden menunjukkan bahwa semua variabel dalam penelitian ini memiliki nilai Cronbach alpha yang lebih tinggi dari yang disyaratkan yaitu sebesar 0,6. Maka hasil instrumen ini dapat dikatakan reliabel.

Hasil uji $\mathrm{F}$ diperoleh nilai $\mathrm{f}_{\text {hitung }}$ sebesar 22,450 dengan tingkat signifikan 0,000.
Karena nilai probabilitas $<0,05$ yaitu $(0,000<$ 0,05), maka hipotesis (Ho) ditolak dan hipotesis (Ha) diterima. Artinya variabel Negara Asal Produk (Country of Origin), Persepsi Kualitas dan Merek secara bersamasama (simultan) berpengaruh positif dan signifikan atas variabel Keputusan Pembelian smartphone di Kota Jambi. Menurut Kotler dan Keller (2009), keputusan pembelian adalah tahap evaluasi konsumen untuk membentuk preferensi di antara merek dalam menetapkan pilihan. Keputusan juga adalah bentuk pemilihan dan minat untuk membeli merek yang paling disukai diantara sejumlah merek yang berbeda. Dalam membeli dan mengkonsumsi sesuatu, terlebih dahulu konsumen membuat keputusan mengenai produk apa yang dibutuhkan, kapan, bagaimana dan dimana proses pembelian atau konsumsi itu akan terjadi. Dalam tahap evaluasi tersebut, negara asal produk (Country of Origin), persepsi kualitas dan merek bisa termasuk dalam tolak ukur konsumen untuk memutuskan membeli jenis produk apa yang dinilai sesuai dengan kebutuhannya.

Tabel 1. Analisis Regresi Linier Berganda

\begin{tabular}{llrrrrr}
\hline & & \multicolumn{2}{c}{$\begin{array}{c}\text { Unstandardized } \\
\text { Coefficients }\end{array}$} & $\begin{array}{c}\text { Standardized } \\
\text { Coefficients }\end{array}$ & \multirow{2}{*}{ t } & Sig. \\
\cline { 3 - 5 } & Model & \multicolumn{1}{c}{ B } & \multicolumn{1}{c}{ Std. Error } & Beta & & \\
\hline \multirow{2}{*}{1} & (Constant) & 7,913 & 1,329 & & 5,952 &, 000 \\
& Country of Origin (X1) &,- 055 &, 033 &,- 137 & $-1,673$ &, 097 \\
& Persepsi Kualitas (X2) &, 198 &, 050 &, 361 & 3,988 &, 000 \\
& Merek (X3) &, 316 &, 089 &, 351 & 3,559 &, 001 \\
\hline
\end{tabular}

Sumber: Data primer diolah, 2018

\section{Regresi Linier Berganda}

Analisis regresi linier berganda digunakan untuk mengetahui dan memprediksi arah hubungan antara variabel terikat dengan variabel bebas. Selengkapnya analisis regresi liniear berganda dapat dilihat pada Tabel 1 . Berdasarkan tabel tersebut dapat digambarkan persamaan sebagai berikut:

$Y=7,913-0,055 X_{1}+0,198 X_{2}+0,316 X_{3}+e$
Persamaan regresi tersebut dapat dijelaskan sebagai berikut:

a. Koefisien konstanta sebesar 7,913 dapat diartikan apabila variabel Country of Origin, persepsi kualitas dan merek dianggap konstan atau tidak mengalami perubahan, maka keputusan pembelian konsumen menjadi sebesar 7,913. 
b. Nilai koefisien Country of Origin $(\mathrm{X} 1)=$ $-0,055, \quad(\mathrm{t})=-1,673$ serta tingkat signifikansi sebesar 0,097 yang lebih besar dari 0,05 . Artinya variabel Country of Origin berpengaruh negatif terhadap keputusan pembelian konsumen dan tidak signifikan. Setiap kenaikan variabel Country of Origin sebesar satu satuan maka akan mengakibatkan keputusan pembelian konsumen turun sebesar 0,055 dengan asumsi bahwa variabel lain adalah konstan atau tidak mengalami perubahan.

c. Nilai koefisien Persepsi kualitas (X2) = $0,189,(t)=3,988$ dan tingkat signifikansi sebesar 0,00 yang lebih kecil dari 0,05. Artinya variabel Persepsi Kualitas ber pengaruh positif terhadap keputusan pembelian konsumen dan signifikan.
Setiap kenaikan variabel persepsi kualitas sebesar satu satuan maka mengakibatkan keputusan pembelian konsumen menjadi meningkat sebesar 0,189 dengan asumsi bahwa variabel lain adalah konstan atau tidak mengalami perubahan.

d. Nilai koefisien Merek $(X 3)=0,316$, $(\mathrm{t})=$ 3,559 dan tingkat signifikansi sebesar 0,001 yang lebih kecil dari 0,05 . Artinya variabel merek memiliki pengaruh positif terhadap keputusan pembelian konsumen dan signifikan. Setiap kenaikan variabel merek sebesar satu satuan maka akan mengakibatkan keputusan pembelian konsumen meningkat sebesar 0,316 dengan asumsi bahwa variabel lain adalah konstan atau tidak mengalami perubahan.

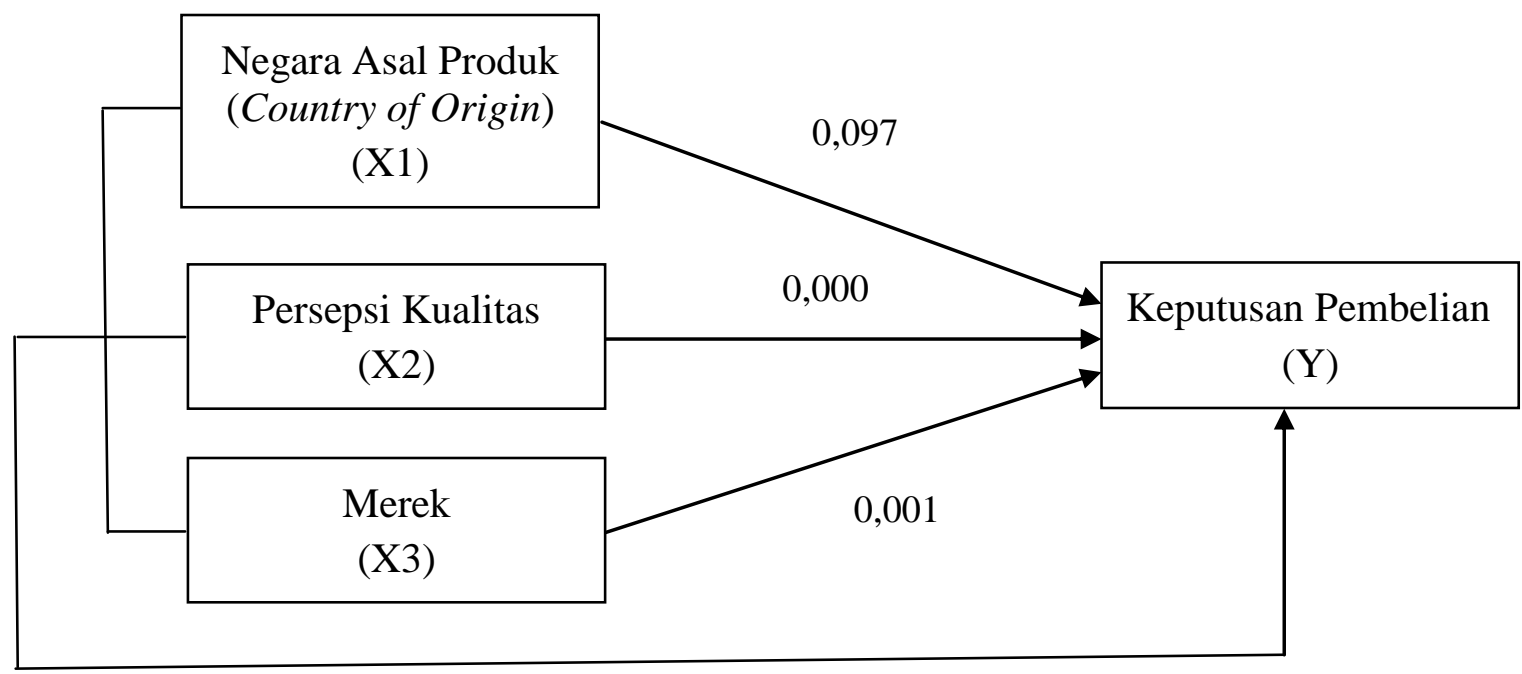

Sumber: Data primer diolah, 2018

Gambar 1. Model Penelitian

Tabel 2. Hasil Uji Koefisien Determinasi $\mathbf{R}^{2}$

\begin{tabular}{ccccc}
\hline Model & $\mathrm{R}$ & $\mathrm{R}$ Square & $\begin{array}{c}\text { Adjusted } \mathrm{R} \\
\text { Square }\end{array}$ & $\begin{array}{c}\text { Std. Error of the } \\
\text { Estimate }\end{array}$ \\
\hline 1 &, $606^{\mathrm{a}}$ &, 367 &, 351 & 189,709 \\
\hline
\end{tabular}

Sumber: Data primer diolah, 2018

\section{Koefisien Determinasi}

Koefisien determinasi merupakan besaran proporsi dari varians dalam variable dependen yang dapat diprediksi dari variable independen. Hasil uji koefisisn determinasi disajikan pada Tabel 2.
Berdasarkan hasil di dalam Tabel 2 diperoleh nilai koefisien determinasi $\left(\mathrm{R}^{2}\right)$ sebesar 0,367 yang berarti bahwa besarnya kontribusi variabel country of origin, persepsi kualitas, dan merek terhadap keputusan pembelian smartphone di Kota Jambi adalah 
$36,7 \%$. Sedangkan selebihnya yakni $63,3 \%$ dipengaruhi faktor lain yang tidak termasuk dalam penelitian ini.

\section{Hasil Pengujian Secara Simultan}

Uji simultan atau uji $\mathrm{F}$ digunakan untuk mengetahui apakah seluruh variabel bebas secara simultan mempunya pengaruh terhadap variabel terikat. Selanjutnya hasil analisis uji F dapat dilihat pada Tabel 3.

Hasil uji $F$ diperoleh nilai $F_{\text {hitung }}$ sebesar 22,450 dengan tingkat signifikan 0,000 . Karena nilai probabilitas < 0,05 (yaitu: 0,000 $<$ 0,05), maka hipotesis (Ho) ditolak dan hipotesis (Ha) diterima. Artinya variabel Negara Asal Produk (Country of Origin), Persepsi Kualitas dan Merek secara bersamasama (simultan) memberi pengaruh secara signifikan terhadap Keputusan Pembelian smartphone di Kota Jambi. Menurut Kotler dan Keller (2009), keputusan pembelian adalah tahap evaluasi konsumen untuk membentuk preferensi di antara merek dalam menetapkan pilihan. Dalam membeli dan mengkonsumsi sesuatu terlebih dahulu konsumen membuat keputusan mengenai produk apa yang dibutuhkan, kapan, bagaimana dan dimana proses pembelian atau konsumsi itu akan terjadi. Dalam tahap evaluasi tersebut, negara asal produk (country of origin), persepsi kualitas dan merek, bisa termasuk dalam tolok ukur konsumen untuk memutuskan membeli produk apa yang sesuai dengan kebutuhannya.

\section{Pengaruh Country of Origin terhadap Keputusan Pembelian}

Hasil uji t untuk variabel Negara Asal Produk (Country of Origin) menunjukkan nilai $t_{\text {hitung }}$ sebesar $-1,673$ dengan nilai signifikan sebesar 0,097 yang lebih besar dari 0,05 atau 5\%. Maka keputusannya adalah menerima hipotesis (Ho) dan menolak hipotesis (Ha); artinya secara parsial variabel Negara Asal Produk (Country of Origin) tidak memiliki pengaruh positif dan signifikan terhadap keputusan pembelian smartphone di Kota Jambi. Hasil tersebut mengindikasikan, walaupun konsumen mengenal baik negara asal produk smartphone yang beredar di pasar Indonesia, tidak mempengaruhi keputusan pembelian mereka terhadap produk tersebut.

Berdasarkan pengamatan, kondisi yang teridentifikasi tersebut dapat disebabkan karena indikator pada variabel country of origin pada kuesioner menggambarkan negara asal produk secara umum tanpa mengacu kepada negara tertentu, sehingga responden dalam penelitian ini hanya menilai suatu produk hanya berdasarkan negara asal secara umum. Responden dalam penelitian ini dominan berada pada rentang usia 17 sampai dengan 21 tahun, memiliki status sebagai pelajar/mahasiswa dengan sifat penggunaan smartphone yang lebih banyak untuk kebutuhan akses internet.

Tabel 3. Hasil Uji F

\begin{tabular}{rlrrrrr}
\hline \multirow{2}{*}{ Model } & & $\begin{array}{l}\text { Sum of } \\
\text { Squares }\end{array}$ & df & $\begin{array}{l}\text { Mean } \\
\text { Square }\end{array}$ & F & \multirow{2}{*}{ Sig. } \\
\hline 1 & Regression & 242,391 & 3 & 80,797 & 22,450 & \multirow{2}{*}{000} \\
& Residual & 417,476 & 116 & 3,599 & & \\
& Total & 659,867 & 119 & & & \\
\hline
\end{tabular}

Sumber: Data primer diolah, 2018

Menurut teori perilaku konsumen (Kotler \& Keller, 2016), faktor-faktor yang dinilai mempengaruhi konsumen dengan karakteristik tersebut ialah faktor personal atau pribadi. Responden seperti ini lebih mengutamakan teknologi dan spesifikasi yang dicerminkan pada produk smartphone serta pengalaman penggunaan yang sesuai dengan kebutuhan mereka dibandingkan melihat darimana negara asal produk tersebut. Konsumen tidak membeli produk berdasarkan kesukaan terhadap negara tertentu dimana 
produk tersebut diproduksi. Hasil penelitian ini mendukung penelitian yang dilakukan sebelumnya oleh Wahyu et al. (2015) yang menyatakan bahwa variabel country of origin tidak berpengaruh secara signifikan terhadap keputusan pembelian.

\section{Pengaruh Persepsi Kualitas terhadap Keputusan Pembelian}

Hasil uji t untuk variabel Persepsi Kualitas menunjukkan nilai $t_{\text {hitung }}$ sebesar 3,988 dengan nilai signifikan sebesar 0,000 yang lebih kecil dari 0,05 atau 5\%. Maka keputusannya adalah menolak hipotesis (Ho) dan menerima hipotesis (Ha), artinya secara parsial variabel Persepsi Kualitas memiliki pengaruh positif dan signifikan terhadap keputusan pembelian smartphone di Kota Jambi. Hasil ini menunjukkan semakin tinggi persepsi kualitas konsumen atas smartphone maka semakin besar pula keputusan mereka untuk membeli smartphone tersebut. Begitu pula sebaliknya, semakin rendah persepsi kualitas konsumen terhadap smartphone maka semakin kecil pula keputusan pembelian mereka.

Kondisi tersebut dapat dikarenakan responden dalam penelitian ini mayoritas telah menggunakan smartphonenya selama lebih dari 1,5 tahun. Semakin lama produk smartphone digunakan akan semakin terasa kemampuan kinerja, ketahanan, kehandalan dan hasil yang akan mencerminkan kualitas dari produk tersebut apakah sesuai dengan yang diharapkan. Pihak responden dapat mempersepsikan kualitas smartphone melalui pengalaman yang telah mereka alami pada smartphone selama mereka menggunakannya. Persepsi kualitas smartphone Samsung dinilai konsumen memiliki keunggulan secara keseluruhan. Persepsi kualitas yang baik diperoleh konsumen ketika melibatkan panca indera (sensory reception) dengan melihat, mendengar, menyentuh dan merasakan langsung penggunaan smartphone Samsung. Hasil penelitian ini mendukung penelitian yang telah dilakukan sebelumnya oleh Maindoka et al. (2014) yang menyatakan bahwa persepsi kualitas memiliki pengaruh positif terhadap keputusan pembelian.

\section{Pengaruh Merek terhadap Keputusan Pembelian}

Hasil uji $t$ untuk variabel merek menunjukkan nilai $t_{\text {hitung }}$ sebesar 3,559 dengan nilai signifikan sebesar 0,001 yang lebih kecil dari 0,05 atau 5\%. Maka keputusannya adalah menolak hipotesis (Ho) dan menerima hipotesis (Ha), artinya secara parsial variabel merek memiliki pengaruh positif dan signifikan terhadap keputusan pembelian smartphone di Kota Jambi. Hasil ini menunjukkan bahwa semakin baik merek smartphone di dalam benak konsumen, maka semakin besar pula keputusan konsumen untuk membeli smartphone tersebut. Begitu pula sebaliknya, semakin buruk merek smartphone di dalam benak konsumen maka semakin kecil pula keputusan pembelian konsumen terhadap smartphone merek Samsung.. Berdasarkan analisis, kondisi ini dapat disebabkan karena responden dalam penelitian ini paling banyak ialah pengguna smartphone merek Samsung.

Samsung adalah merek yang telah memiliki nama besar yang baik di pasar smartphone Indonesia dibandingkan para pesaingnya sehingga hal tersebut menandakan bahwa merek yang kuat dapat mendorong pengambilan keputusan pembelian oleh konsumen. Smartphone buatan Samsung selalu dikenal memiliki kualitas yang bagus. Samsung membekali produknya dengan fiturfitur yang disesuaikan dengan perkembangan kebutuhan teknologi terkini karena senantiasa mampu menjadi pelopor dan menerapkan inovasi dibandingkan kompetitornya. Merek yang sukses dapat menciptalan kesan positif dalam benak konsumen sehingga mengurangi resiko pembelian serta mempengaruhi keputusan pembelian. Hasil penelitian ini mendukung beberapa penelitian yang pernah dilakukan sebelumnya, antara lain penelitian oleh Godey et al. (2012) serta Purwitasari et al. (2018) yang menyatakan bahwa variabel merek berpengaruh positif terhadap keputusan pembelian.

\section{KESIMPULAN}

Berdasarkan hasil-hasil penelitian yang diperoleh, maka disimpulkan beberapa hal. Pertama, variabel Negara Asal Produk 
(Country of Origin) secara parsial tidak berpengaruh positif dan signifikan terhadap keputusan pembelian smartphone di Kota Jambi. Hal ini menyatakan bahwa, walaupun konsumen mengenal baik negara asal produk smartphone yang beredar, tidak akan mempengaruhi keputusan pembelian mereka terhadap produk tersebut.

Kedua, variabel Persepsi Kualitas secara parsial berpengaruh positif dan signifikan terhadap keputusan pembelian smartphone di Kota Jambi. Hal ini menyatakan bahwa semakin tinggi persepsi kualitas konsumen terhadap smartphone maka semakin besar pula keputusan mereka untuk membeli smartphone tersebut. Begitu pula sebaliknya, semakin rendah persepsi kualitas konsumen terhadap smartphone maka semakin kecil pula keputusan pembelian mereka.

Ketiga, variabel Merek secara parsial berpengaruh positif dan signifikan terhadap keputusan pembelian smartphone di wilayah Kota Jambi. Hal ini menyatakan bahwa semakin baik merek smartphone di mata konsumen maka semakin besar pula keputusan mereka untuk membeli smartphone tersebut. Begitu pula sebaliknya, semakin buruk merek smartphone dimata konsumen maka semakin kecil pula keputusan pembelian mereka.

Keempat, variabel Negara Asal Produk (Country of Origin), Persepsi Kualitas, dan Merek secara simultan berpengaruh positif dan signifikan terhadap keputusan pembelian smartphone di Kota Jambi. Hal ini menyatakan bahwa negara asal produk, persepsi kualitas, dan merek secara bersamasama (simultan) akan mempengaruhi konsumen dalam pengambilan keputusan pembelian smartphone.

Berdasarkan kesimpulan-kesimpulan itu maka bisa direkomendasikan beberapa hal sebagai berikut. Pertama, bagi perusahaan smartphone diharapkan dapat terus meningkatkan kualitas serta citra merek yang baik agar konsumen memiliki persepsi kualitas yang positif serta kepercayaan terhadap merek yang tinggi mengingat persaingan pasar smartphone di Indonesia cukup ketat. Konsumen tidak begitu memperhatikan darimana produk tersebut berasal jika produk mampu membangun persepsi kualtas dan merek yang baik.

Selanjutnya, bagi peneliti diharapkan penelitian ini dapat ditingkatkan dan mampu membantu para peneliti lainnya dengan menjadikannya sebagai referensi untuk penelitian selanjutnya. Dengan demikian, peneliti selanjutnya dapat mengembangkan penelitian ini lebih jauh baik dari metode, objek, serta tempat penelitian.

Terakhir, hasil koefisien determinasi $\mathrm{R}^{2}$ dalam penelitian ini menyatakan bahwa kontribusi Negara Asal Produk (Country of Origin), Persepsi Kualitas dan Merek untuk mempengaruhi keputusan pembelian atas smartphone adalah sebesar $36,7 \%$, sedangkan selebihnya yakni $63,3 \%$ dipengaruhi faktorfaktor lain yang tidak diteliti dalam penelitian ini. Maka dari itu, bagi peneliti selanjutnya diharapkan dapat mengembangkan penelitian ini dengan menambah faktor-faktor yang tidak diteliti dalam penelitian ini seperti misalnya harga, desain, promosi, kelompok referensi dan lain-lain.

\section{DAFTAR PUSTAKA}

Czinkota, M.R. dan Ronkainen, I.A. 2013. International Marketing. South Western: Cengage Learning.

Durianto, D., Sugiarto dan Sitinjak, T. 2001. Strategi Menaklukkan Pasar Melalui Riset Ekuitas dan Perilaku Merek. Jakarta: PT. Gramedia Pustaka Utama.

eMarketer. 2015. Asia-Pacific Boasts More than 1 Billion Smartphone Users. available at: www.emarketer.com/ Article/Asia-Pacific-Boasts-MoreThan-1-Billion-Smartphone-Users/ 1012984\#sthash.jfgvBKh8.dpuf (accessed March 11, 2016)

Filieri, R., Chen, W. dan Lal, D.B. 2017. The Importance of Enhancing, Maintaining and Saving Face in Smartphone Purchase Intentions of Chinese Early Adopter. Available at: www.emeraldinsight.com/09593845.htm 
Godey, B., Pederzoli, D., Aiello, G., Donvito, R., Chan, P., Oh, H., Singh, R., Skorobogatykh, I.I., Tsuchiya, J. dan Weitz, B. 2011. Brand and Country of Origin Effect on Consumers Decision to Purchase Luxury Products. Journal of Bussines Research. Vol. 65, No. 10, hal. 1461-1470.

Hair, J.F. 2010. Multivariate Data Analysis a Global Perspective. 7th Edition. US: Pearson.

Hoyer, W.D., MacInni, D.J., dan Pieters, R. 2013. Consumer Behavior. $6^{\text {th }}$ Edition. South-Western: Cengage Learning.

Keller, K.L. 2013. Strategic Brand Management. 4th Edition. US: Pearson.

Kotler P. dan Keller, K.L. 2016. Marketing Management. $15^{\text {th }}$ Global Edition. US: Pearson.

Laksana, N.C. 2018. Masyarakat Indonesia Lebih Suka Buka Internet Via Smartphone.

https://techno.okezone.com/read/2018/0 4/04/207/1882130/masyarakat-

indonesia-lebih-suka-buka-internet-viasmartphone. Diakses 27 Oktober 2018.

Loudon, D.L. dan Delabitta, A.J. 1999. Consumer Behavior. New York: Prentice Hall.

Maindoka, R., Lapian, J. dan Tumewu F. 2014. Brand Image and Perceived Quality on Consumer Buying Decision of Samsung Mobile Phone in Manado. Jurnal EMBA. Vol. 1, No. 2, hal. 985922.

Nielsen. 2014. How Smartphones are Changing Consumers' Daily Routines Around the Globe. Available at: www.nielsen.com/us/en/insights/news/2 014/how-smartphones-arechangingconsumersdaily-routines-around-theglobe.html. (accessed March 10, 2014).

Persaud, A. dan Azhar, I. 2012. Innovative Mobile Marketing via Smartphones: are Consumers Ready? Marketing
Intelligence \& Planning. Vol. 30, No. 4, hal. 418-443.

Purwitasari, P., Yulianto, E. dan Wilopo. 2018. Pengaruh Merek dan Negara Asal (Country of Origin) terhadap Keputusan Pembelian (Survei pada Mahasiwa Pengguna Oppo atau Samsung Smartphone di Fakultas Ilmu Administrasi Angkatan Tahun 2013-2015). Jurnal Administrasi Bisnis. Vol. 61, No.1, hal. 100-108.

Sanyal, S.N. dan Saroj, K.D. 2011. The Effect of Country Origin on Brand Equity: An Empirical Study on Generic Drugs. Journal of Product \& Brand Management. Vol. 20, No. 2, hal. 130140.

Sriayudha, Y. 2013. Pengaruh Experiential Marketing terhadap kepuasan Konsumen Pengguna Samsung Galaxy Tab. Universitas Jambi. Laporan Penelitian. Jambi: Universitas Jambi.

Sugiyono. 2013. Metode Penelitian Manajemen. Bandung: Alfabeta.

Tati, W.P., Suharyono dan Yulianto, E. 2015. Pengaruh Country of Origin dan Global Brand Image terhadap Minat Beli dan Keputusan Pembelian (Survei pada Konsumen yang Membeli Smartphone Samsung Galaxy di Asia Tenggara). Jurnal Administrasi Bisnis. Vol. 25, No. 1, hal. 1-10.

Yunus, N.S.N.M. dan Rashid, W.E.W. 2015. The Influence of Country-of-Origin on Consumer Purchase Intention: The Mobile Phones Brand from China. Procedia Economics and Finance. Vol. 37, Hal. 343-349.

Yusu, O. 2018. Survei Canalys: Xiaomi Vendor Ponsel Terbesar ke-2 di Indonesia. https://tekno.kompas.com/ $\mathrm{read} / 2018 / 05 / 15 / 08274587 /$ surveicanalys-xiaomi-vendor-ponsel-terbesarke-2-di-indonesia. Diakses tanggal 24 September 2018. 